\title{
Supporting Information for: Aging Effects on Biomass Burning Aerosol Mass and Composition: A Critical Review of Field and Laboratory Studies
}

Anna L. Hodshire ${ }^{1}$, Ali Akherati ${ }^{2}$, Matthew J. Alvarado ${ }^{3}$, Benjamin Brown-Steiner ${ }^{3}$, Shantanu H. Jathar $^{2}$, Jose L. Jimenez ${ }^{4}$, Sonia M. Kreidenweis ${ }^{1}$, Chantelle R. Lonsdale ${ }^{3}$, Timothy B. Onasch ${ }^{5}$, Amber M. Ortega ${ }^{6 *}$, Jeffrey R. Pierce ${ }^{1}$

${ }^{1}$ Department of Atmospheric Science, Colorado State University, Fort Collins, CO, USA

${ }^{2}$ Department of Mechanical Engineering, Colorado State University, Fort Collins, CO, USA

${ }^{3}$ Atmospheric and Environmental Research, Inc., Lexington, Massachusetts, USA

${ }^{4}$ Dept. of Chemistry and Cooperative Institute for Research in Environmental Sciences (CIRES), University of Colorado, Boulder, CO 80309, USA

${ }^{5}$ Aerodyne Research Inc., Billerica, Massachusetts, USA

${ }^{6}$ Dept. Atmospheric and Oceanic Sciences Department and Cooperative Institute for Research in Environmental Sciences (CIRES), University of Colorado, Boulder, CO 80309, USA

*Now at Air Pollution Control Division, Colorado Department of Public Health and Environment, Denver, CO, 80246, USA

\section{Summary of Supporting Information}

$\underline{\text { Text }}$

S1. Additional field campaign information

S2. Additional laboratory campaign information

S3. Discussion of Aerosol Mass Spectrometer collection efficiency

S4. Description of tubing wall loss estimates for laboratory campaigns

Tables

Table S1. Field campaigns from Figure 1A

Figures

Figure S1. Results for each experiment within the laboratory campaigns of Figure 1B arranged by fuel type.

Figure S2. The estimated photochemical age for each residence (actual) time of each aging experiment within the laboratory campaigns of Figure $1 \mathrm{~B}$, colored by OA enhancement ratio $\left(\mathrm{OA}_{\mathrm{ER}}\right)$.

Figure S3. The field studies of Figure 1A, B arranged by geographic region.

Figure S4. The OA enhancement ratio to the modified combustion efficiency (MCE) for each chamber for all experiments within the laboratory campaigns of Figure 1B. Symbols indicate fuel type and colors indicate study type.

Figure S5. The O:C $\mathrm{C}_{\mathrm{ER}}$ (left y axis; closed symbols) and $f_{44} / f_{60_{E R}}$ (right y axis; open symbols) values to the initial OA concentration in $\mu \mathrm{g} \mathrm{m}^{-3}$ within each chamber for all experiments within the laboratory campaigns of Figure $1 \mathrm{~B}$. 
Figure S6. Two-dimensional histogram of the annual data for the United States in 2014 for the number of recorded fires by fire size in $\mathrm{km}^{2}$ blackened per day (that is, the total area in $\mathrm{km}^{2}$ burned per day) from the National Emissions Inventory (U.S. EPA NEI, 2014) against the nonsmoke background $\mathrm{PM}_{2.5}$ that each fire diluted into and total annual $\mathrm{PM}_{2.5}$ emissions in $\mathrm{kg}$ from each fire size for 2014 from the same dataset against the background $\mathrm{PM}_{2.5}$ that each fire diluted into.

Figure S7. The box-and-whiskers for the $\mathrm{OA}$ enhancement ratios $\left(\mathrm{OA}_{\mathrm{ER}}\right)$ smog chamber at FLAME III (Hennigan et al., 2011) and the model results of Bian et al., (2017) for partitioning of vapors to the chamber walls on and off.

Figure S8. Estimated gas-phase losses of smoke to the transfer lines (tubing) between the burn chamber and the smog chamber, using the setup for FLAME III (Hennigan et al., 2011), assuming the line has been heated from $23{ }^{\circ} \mathrm{C}$ to $40{ }^{\circ} \mathrm{C}$ and using the Teflon tubing model built in Pagonis et al. (2017). 


\section{Text S1. Additional field campaign information}

All studies in Figure $1 \mathrm{~A}$ provide $\Delta \mathrm{OA} / \Delta \mathrm{CO}$ from Aerosol Mass Spectrometer (AMS) instruments except the SAFARI observations detailed in Hobbs et al. (2003) and the Vakkari et al. (2014, 2018) studies. Hobbs et al. (2003) provided total excess particulate matter $(\Delta T P M)$ divided by $\triangle \mathrm{CO}$, as measured by Teflon filters. Although Hobbs et al. (2003) determined a net decrease in $\mathrm{PM}_{\mathrm{ER}}$ to 0.5 after 0.65 hours of physical (actual) aging for SAFARI, Alvarado and Prinn (2009) provided an alternative analysis to the SAFARI observations that indicated that the initial reported mass was likely biased high. We use the Alvarado and Prinn (2009) corrected $\triangle T P M$ to obtain a final $\mathrm{PM}_{\mathrm{ER}}$ of 1.7 and include both the corrected and uncorrected points in Figure 1A. Vakkari et al. $(2014,2018)$ provided total mass of all particles $1 \mu \mathrm{m}$ in diameter and smaller, $\Delta \mathrm{PM}_{1}$, normalized by $\Delta \mathrm{CO}$, as measured by a differential mobility particle sizer (assuming a density of $1.485 \mathrm{~g} \mathrm{~cm}^{-3}$ ).

\section{Text S2. Additional laboratory campaign information}

For all experiments, the selected fuel was allowed to completely burn, fill the FSL chamber, and become well-mixed ( 20 minutes). The FLAME III smog chamber and OFR as well as 12 of the FLAME IV smog chamber experiments sampled from the FSL chamber ("chamber burn"). The FIREX experiments and 7 experiments from the FLAME IV smog chamber (Tkacik et al., 2017) instead sampled directly from the FSL exhaust stack ("stack burn"). For each experiment, the fuel was burned to completion.

The FLAME III campaign used two different study designs: Hennigan et al. (2011) used a $7 \mathrm{~m}^{3}$ environmental ("smog") chamber located directly outside of the FSL facility, with instrumentation for characterizing the chamber experiments in a mobile laboratory parked beside the chamber. A heated (to $40 \mathrm{C}$ ) $12 \mathrm{~m}$ stainless steel transfer line with two ejector dilutors pulled smoke at a rate of $15 \mathrm{~L} \mathrm{~min}^{-1}$ from the FSL burn chamber to the smog chamber. For each experiment, the transfer line was conditioned with smoke for 30 minutes before filling the chamber to reduce losses of semivolatile compounds. Ortega et al. (2013) used a 13.1 L oxidation flow reactor (OFR) located within the FSL burn chamber itself with instrumentation for characterizing the OFR experiments located directly outside of the burn chamber. The smog chamber produced $\mathrm{OH}$ in four different ways: with natural sunlight only; with UV lights; with both UV lights and sunlight; with UV lights and an injection of $\mathrm{HONO}$, producing further $\mathrm{OH}$ with the reaction $\mathrm{HONO}+\mathrm{h} v=\mathrm{OH}+\mathrm{NO}$; and with UV lights, $\mathrm{HONO}$, and natural sunlight. The OFR produced both $\mathrm{OH}$ and $\mathrm{O}_{3}$ from UV lights, but the $\mathrm{OH} / \mathrm{O}_{3}$ ratio was approximately 10 times that of ambient daylight levels. Typically, reaction rates of vapors with $\mathrm{OH}$ are more rapid than those with $\mathrm{O}_{3}$ (Atkinson and Arey, 2003), and thus it was assumed that $\mathrm{OH}$ was the dominant reactant in the OFR. The smog chamber sampled 18 burns and 12 distinct fuel types; the OFR sampled 25 different burns and 16 distinct fuel types.

In FLAME IV, Tkacik et al. (2017) used a dual-chamber design: two identical $7 \mathrm{~m}^{3}$ Teflon smog chambers were located within the FSL burn chamber, with instrumentation for characterization located in a mobile laboratory parked directly outside of the FLS facility. The dual-chamber setup allowed for simultaneous characterizations of a single burn under different perturbations. The dual-chamber used $\mathrm{OH}$ and/or $\mathrm{O}_{3}$ as the primary oxidant. $\mathrm{OH}$ was produced using UV lights or UV lights $+\mathrm{HONO}$. In the $\mathrm{O}_{3}$ experiments, ozone was directly injected into the chamber and was kept otherwise dark in order to test the effects of ozone only ("dark $\mathrm{O}_{3}$ "). 
Most of the experiments held one chamber as a reference chamber, allowing the smoke to age in the dark without additional oxidants added, although a few experiments directly compared one oxidant type to another. Nineteen burns and 8 distinct fuel types were studied. For the chamber burns, smoke was transferred at $24 \mathrm{~L} \mathrm{~min}^{-1}$ to each chamber using two ejection dilutors and a $3.048 \mathrm{~m}$ stainless steel line, heated to $40 \mathrm{C}$. Similar to FLAME III, the transfer lines were conditioned with smoke for 30 minutes before filling the chambers for each experiment.

For FIREX, Jathar et al. (in prep) used a $10 \mathrm{~m}^{3}$ chamber, similar to Hennigan et al. (2011), to perform day- $\left(\mathrm{w} / \mathrm{OH}\right.$ and $\left.\mathrm{O}_{3}\right)$ and night-time $\left(\mathrm{w} / \mathrm{NO}_{3}\right)$ aging experiments. The nighttime experiments were not included in this review. The $\mathrm{OH}$ experiments were performed with either $\mathrm{HONO}$ or $\mathrm{H}_{2} \mathrm{O}_{2}$ as the $\mathrm{OH}$ precursors, $\mathrm{O}_{3}$ experiments were performed by injecting $\mathrm{O}_{3}$ before addition of smoke, and the $\mathrm{NO}_{3}$ experiments were performed by adding $\mathrm{NO}$ and $\mathrm{O}_{3}$ to allow the gradual build up of $\mathrm{NO}_{3}$ before smoke was added. Smoke was transferred by an unheated aluminum transfer line, $\sim 25 \mathrm{~m}$ long. Six different fuels found in the western US were used to perform a total of 16 experiments, alongside two chamber blanks.

To determine the initial condition of the smoke, each smog chamber burn underwent a primary characterization period of $\sim 2-120$ minutes before an oxidant was applied. Due to the short residence time of the OFR, this study instead had a copper bypass line that sampled unprocessed smoke from the FSL chamber and aged smoke from the OFR, switching between the reactor and the bypass line with 1 minute time resolution, and thus the unprocessed smoke in the FSL chamber was assumed to be the initial condition of the smoke within the OFR.

Figure S2 provides the final photochemical age versus the residence (physical) time for each study where reported, colored by $\mathrm{OA}_{\mathrm{ER}}$. The residence time within the FLAME III smog chamber experiments was between 3-4.5 hours, with total equivalent photochemical ages ranging between 2.6 and 15.1 equivalent hours. The FLAME III OFR reactor had an average residence time of 180 seconds, with total photochemical ages exceeding 72-120 equivalent hours. However, Figure $1 \mathrm{C}$ shows the observed maximum $\mathrm{OA}$ enhancement ratio $\left(\mathrm{OA}_{\mathrm{ER}}\right)$ from the FLAME III OFR, which occurred between 40 and 105.6 equivalent hours (Ortega et al., 2013). In Tkacik et al. (2017), the FLAME IV smog chambers experiments had a residence time of 2 hours, with calculated photochemical ages ranging between 1-25 equivalent hours. We note that the photochemical ages during FLAME IV were calculated in only a quarter of the experiments and are deemed to be uncertain. Ahern et al. (2019) instead calculated all enhancements after 1.5 hours of actual aging. The FIREX smog chamber experiments had a residence time of 1-6 hours, with calculated photochemical ages between 0.3 and 8.2 equivalent hours.

All photochemical ages except the dual chamber are calculated using the estimated total $\mathrm{OH}$ exposure per experiment and assuming that 1 day of aging is equivalent to $1.5 \times 10^{6}$ molec day $\mathrm{cm}^{-3}$ of $\mathrm{OH}$ exposure (Palm et al., 2016). The FLAME IV chambers instead assume that 1 day of aging is equivalent to $\mathrm{OH}$ and $\mathrm{O}_{3}$ concentrations of $2 \times 10^{6}$ molec $\mathrm{cm}^{-3}$ and $60 \mathrm{ppb}$, respectively.

There were four methods that PWL was corrected for in these studies:

(1) Hennigan et al., (2011), Tkacik et al., (2017), and FIREX followed Grieshop et al. (2009):

$$
\mathrm{OA}_{\mathrm{ER}}=\frac{O A_{t} / B C_{t}}{O A_{0} / B C_{0}}(\mathrm{Eq} 4)
$$

where $\mathrm{OA}_{t}$ and $\mathrm{BC}_{t}$ are the $\mathrm{OA}$ and $\mathrm{BC}$ concentrations at time $\mathrm{t}$ and $\mathrm{OA}_{0}$ and $\mathrm{BC}_{0}$ are the $\mathrm{OA}$ and $\mathrm{BC}$ concentrations during the initial characterization period. Each study assumed that the aerosol 
on the chamber walls can still partition with SVOCs and assumed no mass-transfer limitations of the vapors to the particles on the walls ( $\omega=1$ case; Weitkamp et al., 2007). This method corrects for both particle losses and losses of vapors that partition to the aerosol on the walls. We note that more recent understanding shows that the chamber walls themselves greatly outcompete the deposited particles for vapor absorption (Krechmer et al., 2016), and thus the analyses with $\omega$ are no longer believed to be accurate; however, the reported laboratory results are still greatly sensitive to this choice of $\omega$ and we report both results here. We explore the effect of tubing and wall losses in Section 3.3 and in Text S4.

(2) Hennigan et al. (2011) also determined the PWL rate constant for the decay of OA mass during the primary characterization period ( 75 minutes), and used this to determine particle wall loss. They report upper bound mass enhancements as the mean of this and method 1 above (Figure 1C).

(3) Hennigan et al. (2011) and FIREX provides an estimate for a lower bound enhancement, in which condensable vapors are assumed to only partition to suspended particles ( $\omega=0$ case; Weitkamp et al., 2007). Hennigan et al. (2011) uses method (2) as a basis to calculate their $\omega=0$ cases; FIREX uses method (1) as a basis to calculate their $\omega=0$ cases.

(4) Ahern et al. (2019) instead corrected both for potential AMS collection efficiency (CE) limitations (Donahue et al., 2013; Docherty et al., 2013; Robinson et al., 2017) and chamber wall losses. To correct for changes in CE, they use a low-volatility POA tracer ion and determine SOA production and POA evaporation through the changing relative contribution from the POA tracer ion signal to the total OA ion signal. They then correct for wall losses, using both the $\omega=1$ and $\omega=0$ cases. We note that this approach may be prone to underestimating $\mathrm{CE}$ at longer ages, since the tracer ion may partially be reduced by oxidation or partitioning.

As the residence time is short in the OFR and particle losses are measured to be small, Ortega et al. (2013) instead reports the OA enhancement ratio without correcting for potential wall losses:

$$
\mathrm{OA}_{\mathrm{ER}}=\mathrm{OA}_{\mathrm{t}} / \mathrm{OA}_{0} \quad(\mathrm{Eq} 5)
$$

\section{Text S3. Discussion of Aerosol Mass Spectrometer collection efficiency}

AMS collection efficiencies might vary between fresh and aged aerosol: Some studies have suggested that AMS collection efficiency (CE) of OA could vary with aging (Donahue et al., 2013; Robinson et al., 2017), such that fresh OA emissions could have CE near 1 but aged OA may have a $\mathrm{CE}<=0.5$ (Docherty et al., 2013; Robinson et al., 2017). A similar, perhaps correlated, trend in decreasing sensitivity with increasing oxidation is observed in the AMS RIE (relative ionization efficiency) for laboratory generated single compound OA particles (Xu et al., 2018). However, this effect has only been reported for some chamber studies (for non-biomass burning cases), and is typically not observed for ambient data (Middlebrook et al., 2012). The field studies have evaluated possible changes in CE (and also RIE) by comparison to co-located instruments measuring particle volume (e.g. Liu et al., 2017), and to our knowledge none have reported changes in $\mathrm{CE}^{*} \mathrm{RIE}$ with aging. The same procedure is typically applied in OFR studies (e.g. Palm et al., 2016). In addition, studies using collocated water-soluble organic carbon reached the same conclusions (of lack of mass enhancement) as those with the collocated AMS observations for 500 wildfire plumes sampled from aircraft (Hecobian et al., 2011). Ahern et al. (2019) attempted a correction for the potential change in CE for aged BB aerosol. Their analysis 
shows a much lower mean and median mass enhancement ratio than the Tkacik et al. (2017) analysis of FLAME IV; however, Tkacik et al. (2017) includes 6 extra experiments and OA enhancements at longer ages than Ahern et al. (2019) does and so the two studies are not directly comparable. We note that other instrumental problems such as limited particle transmission at some sizes, or problems with the instruments being compared to, are often incorrectly interpreted as changes in CE. Overall, this issue is unlikely to explain the differences between laboratory and field experiments, but deserves further research.

\section{Text S4. Description of tubing wall loss estimates for laboratory campaigns}

In order to provide an estimate of the importance of losses and delays of vapors to the tubing that transports smoke from the burn chamber floor to a smog chamber, we apply the model developed in Pagonis et al. (2017; hereafter 'tubing model') to the smog-chamber set-up used in FLAME III (Hennigan et al., 2011). Pagonis et al. (2017) modelled the transfer of vapors to the tubing between a smog chamber and a proton-transfer-reaction mass spectrometer as an absorptive partitioning process, finding that rapid partitioning of lower-volatility vapors caused significant delays in their transfer through the tubing. Based on the description in Hennigan et al. (2011), we assumed a tubing length of $12 \mathrm{~m}$, a flow rate of $15 \mathrm{~L} \mathrm{~min}^{-1}$, and a tubing inner diameter of 0.42 inches. We assumed that a continuous flow of smoke entered the chamber for an average time of 15 minutes of smoke per experiment, and ran the model for 15 minutes to determine how much gas-phase material would deposit on the tubing and how much would be transmitted by the end of 15 minutes. The tubing model was developed to estimate vapor losses within a PFA Teflon tube at $23^{\circ} \mathrm{C}$ as a function of $\mathrm{C}^{*}$ (saturation concentration, in units of $\mu \mathrm{g} \mathrm{m}{ }^{-}$ ${ }^{3}$ ), noting that other tubing materials, such as the stainless steel tubing that was actually used in FLAME III, lead to longer delays than Teflon and thus larger effects than simulated here (Deming et al., 2019; Liu et al., 2019). Further discussion of tubing materials is in the final paragraph of this section. We neglect potential particle losses to the tubing. We used the VBS distribution from Bian et al. (2017) and assumed an initial mass loading of $50 \mu \mathrm{g} \mathrm{m}^{-3}$ and initial temperature of $23^{\circ} \mathrm{C}$. As the tubing at FLAME III was heated to $40^{\circ} \mathrm{C}$, we estimated the losses that would occur at both tubing temperatures of $40{ }^{\circ} \mathrm{C}$ and $23{ }^{\circ} \mathrm{C}$ to estimate the impact of heating (Figure S7). The new volatility distribution at $40^{\circ} \mathrm{C}$ was estimated using the ClausiusClapeyron relation (Cappa and Jimenez, 2010):

$C *_{\text {new }}=C *_{\text {initial }}\left(\frac{T_{1}}{T_{2}}\right) \exp \left(-\frac{L}{R}\left(\frac{1}{T_{2}}-\frac{1}{T_{1}}\right)\right) \quad$ Eq. S1

where $C^{*}{ }_{n e w}$ is the volatility at $40^{\circ} \mathrm{C}, L$ is the specific latent heat, $R$ is the specific gas constant (assumed to be $8.314 \mathrm{~J} \mathrm{~mol}^{-1} \mathrm{~K}^{-1}$ ), and $T_{1}$ and $T_{2}$ and $23{ }^{\circ} \mathrm{C}$ and $40{ }^{\circ} \mathrm{C}$, respectively. We assumed $L$ to be $90 \mathrm{~kJ} \mathrm{~mol}^{-1}$, which conveniently allows for $C^{*}{ }_{n e w}$ to shift up by a factor of 10 for $40{ }^{\circ} \mathrm{C}$ relative to $23{ }^{\circ} \mathrm{C}$.

We run two bounding cases for the assumption of the tubing at $40{ }^{\circ} \mathrm{C}$ (Figure S7). Upon heating from $23{ }^{\circ} \mathrm{C}$ to $40^{\circ} \mathrm{C}$, the volatility distribution will shift, with a portion of the aerosol evaporating. However, the residence time for smoke within the tubing was $\sim 4.3$ seconds, which may be fast enough to limit evaporation of the particles (Riipinen et al., 2010). Our lower-bound case (Figure S7a) assumes no aerosol evaporates within the temperature shift. Our upper-bound case assumes the volatility distribution immediately repartitions to equilibrium at $40{ }^{\circ} \mathrm{C}$ (thus providing more gas-phase material; Figure S7b). In both cases, we assume the aerosol does not evaporate further upon vapor wall losses. In Figure S7, we show the amount of gas-phase 
material "lost" to the tubing, as well as the amount of evaporated aerosol lost to the tubing for the upper bound case. We also show the results for if the tubing was not heated and kept at $23{ }^{\circ} \mathrm{C}$ (Figure S7c).

Finally, we estimate the OA enhancement ratios for each case (Figure SS7, D):

$O A_{E R}=\frac{(S O A+P O A)}{P O A} \quad$ Eq. S2

where POA is the assumed POA to enter the chamber $\left(50 \mu \mathrm{g} \mathrm{m}^{-3}\right.$ for the lower bound case at 40 ${ }^{\circ} \mathrm{C}$ and the case at $23{ }^{\circ} \mathrm{C}$, and $\sim 34 \mu \mathrm{g} \mathrm{m}^{-3}$ for the upper bound case at $40{ }^{\circ} \mathrm{C}$, as a portion of the POA is assumed to evaporate upon heating with some evaporated organics being lost to tubing for this case). SOA is calculated assuming that the SOA yield of each bin varies linearly with $\mathrm{C}^{*}$, with a yield of 0.05 for the $C^{*}=10^{7} \mu \mathrm{g} \mathrm{m}^{-3}$ bin and 1 for the $C^{*}=10^{2} \mu \mathrm{g} \mathrm{m}^{-3}$ and lower bins. (Bins above $\mathrm{C}^{*}=10^{7} \mu \mathrm{g} \mathrm{m}^{-3}$ are assumed to not have SOA yields for this calculation). We neglect further wall losses in the smog chamber when calculating $\mathrm{OA}_{\mathrm{ER}}$. We contrast $\mathrm{OA}_{\mathrm{ER}}$ for each case to a case in which no tubing was used (that is, the smoke was instantly transferred from the burn chamber to the smog chamber at $23^{\circ} \mathrm{C}$ ).

An important caveat of this analysis is that although the tubing model was developed based on results for PFA Teflon, the tubing at FLAME III was stainless steel. Deming et al. (2019) shows that dramatically different delay times can occur for absorptive materials (such as Teflon) as compared to adsorptive materials (such as stainless steel), with stainless steel having longer delay times in their study. Thus, parameterizations for adsorptive materials are required to provide a more quantitative estimate of the tubing losses that may have occurred during the smoke experiments. We note that the delay time for adsorptive materials was shown to decrease in Deming et al. (2019) for tubing that had been previously used. In FLAME III, the tubing was pretreated by running smoke through it for 30 minutes prior to each experiment, likely decreasing delay times during the actual experiments. 
Table S1. Field campaigns from Figure 1A.

\begin{tabular}{|c|c|c|c|c|c|c|}
\hline $\begin{array}{l}\text { Study } \\
\text { (references) }\end{array}$ & $\begin{array}{l}\text { Fire type, } \\
\text { environ- } \\
\text { ment }\end{array}$ & $\begin{array}{l}\text { Burn area; } \\
\text { dilution } \\
\text { conditions }\end{array}$ & $\begin{array}{l}\text { Burn } \\
\text { conditions }\end{array}$ & $\begin{array}{l}\text { Initial age (s); } \\
\text { final age(s) of } \\
\text { measurements }\end{array}$ & $\begin{array}{l}\text { Oxidant } \\
\text { concentra- } \\
\text { tions; }\end{array}$ & $\begin{array}{l}\mathrm{MASS}_{\mathrm{ER}}(\text { source }) ; \\
\mathrm{O}: \mathrm{C}_{\mathrm{ER}}(\text { source }) ; \\
f_{44} / f_{60 \mathrm{ER}}(\text { source })\end{array}$ \\
\hline $\begin{array}{l}\text { SAFARI } \\
\text { (Hobbs et } \\
\text { al., 2003; } \\
\text { Alvarado } \\
\text { and Prinn, } \\
\text { 2009) }\end{array}$ & $\begin{array}{l}\text { One } \\
\text { controlled } \\
\text { grassland } \\
\text { burn in } \\
\text { South Africa }\end{array}$ & $10 \mathrm{~km}^{2}$ & $\begin{array}{l}\text { Initial } \\
\mathrm{MCE}= \\
0.94, \text { aged } \\
\mathrm{MCE}= \\
0.93\end{array}$ & $\begin{array}{l}1 \text { minute; } \\
0.65 \text { hrs (A) }\end{array}$ & $\begin{array}{l}\text { In-plume } \\
\text { OH } 1.7 \mathrm{x} \\
10^{7} \text { molec } \\
\mathrm{cm}^{-3} \\
(\text { Hobbs })\end{array}$ & $\begin{array}{l}0.5 \text { (Hobbs; ), } \\
1.7 \text { (Alvarado); } \\
\text { n/a; } \\
\text { n/a }\end{array}$ \\
\hline $\begin{array}{l}\text { SEAC4RS } \\
\text { (Liu et al., } \\
\text { 2016) }\end{array}$ & $\begin{array}{l}7 \text { agriculture } \\
\text { fires in the } \\
\text { U.S. } \\
\text { midwest }\end{array}$ & $\begin{array}{l}0.16 \mathrm{~km}^{2} \text { to } \\
1.27 \mathrm{~km}^{2}\end{array}$ & $\begin{array}{l}\text { Range of } \\
\text { MCE: } 0.895 \\
\text { to } 0.958\end{array}$ & $\begin{array}{l}0 \text { minutes; } \\
\text { Up to } 1.25 \mathrm{hrs} \\
(\mathrm{A})\end{array}$ & $\begin{array}{l}\text { No } \\
\text { discussion }\end{array}$ & $\begin{array}{l}1 \\
1.5-2 \\
\mathrm{n} / \mathrm{a}\end{array}$ \\
\hline $\begin{array}{l}\text { MILAGRO } \\
\text { (DeCarlo et } \\
\text { al., 2008; } \\
\text { Yokelson et } \\
\text { al., 2009; } \\
\text { Jolleys et } \\
\text { al., 2012) }\end{array}$ & $\begin{array}{l}\text { Agricultural } \\
\text { and forest } \\
\text { fires in the } \\
\text { Yucatan } \\
\text { peninsula } \\
\text { (Mexico). }\end{array}$ & $\begin{array}{l}\text { Each fire } \\
\text { assumed to } \\
\text { be } 1 \mathrm{~km}^{2} \\
\text { (Yokelson); } \\
\text { Ave. wind of } \\
2.6 \mathrm{~m} \mathrm{~s}^{-1} \\
\text { (Yokelson) }\end{array}$ & $\begin{array}{l}\text { Yokelson: } \\
0.925 \\
\text { (fresh) but } \\
\text { this is from } \\
\text { a day } \\
\text { earlier. } \\
\text { DeCarlo: no } \\
\text { discussion }\end{array}$ & $\begin{array}{l}\text { DeCarlo: } \\
\text { "Fresher", } \\
\text { Yokelson: 10- } \\
30 \text { minutes, } \\
\text { Jolleys: } \\
\text { "fresh"; } \\
\text { DeCarlo: Up } \\
\text { to } 18 \text { hrs (P), } \\
\text { Yokelson: } 1.4 \\
\text { hrs (A)/12 hrs } \\
(\mathrm{P}), \text { Jolleys: up } \\
\text { to } 24 \text { hrs (P) }\end{array}$ & $\begin{array}{l}\text { In-plume } \\
\mathrm{OH}>10^{7} \\
\text { molec } \mathrm{cm}^{-3} \\
\text { (Yokelson) }\end{array}$ & $\begin{array}{l}0.8 \text { (Jolleys), } 1.3 \\
\text { (DeCarlo), } 2.3 \\
\text { (Yokelson); } \\
1.8-2.7 \text { (DeCarlo); } \\
5.12 \text { (Jolleys) }\end{array}$ \\
\hline $\begin{array}{l}\text { Vakkari et } \\
\text { al., 2014; } \\
2018\end{array}$ & $\begin{array}{l}\text { Savanna, } \\
\text { grassland, } \\
\text { and mixed } \\
\text { cropland, } \\
\text { grassland, } \\
\text { and savanna } \\
\text { burns in S. } \\
\text { Africa }\end{array}$ & $\begin{array}{l}\text { No } \\
\text { discussion }\end{array}$ & $\begin{array}{l}\triangle \mathrm{BC} / \Delta \mathrm{CO}: \\
\mathrm{PM}_{1} \\
\text { enhanceme } \\
\text { nt for } \\
\Delta \mathrm{BC} / \Delta \mathrm{CO} \\
\text { values }< \\
0.02 \\
\text { (unitless) }\end{array}$ & $\begin{array}{l}\text { "Fresh } \\
\text { plumes" less } \\
\text { than } 0.5 \text { hrs } \\
\text { old; average } \\
\text { ages of } 2.4 \\
\text { hours }(2014) \\
\text { and } 3-5 \text { hours } \\
(2018)\end{array}$ & $\begin{array}{l}\text { No } \\
\text { discussion }\end{array}$ & $\begin{array}{l}1.0,2.0-3.0 \\
\mathrm{n} / \mathrm{a} \\
\mathrm{n} / \mathrm{a}\end{array}$ \\
\hline $\begin{array}{l}\text { SCREAM } \\
\text { (May et al., } \\
\text { 2015) }\end{array}$ & $\begin{array}{l}2 \text { prescribed } \\
\text { agricultural } \\
\text { burns in U.S. } \\
\text { (South } \\
\text { Carolina) }\end{array}$ & $\begin{array}{l}0.36 \text { and } \\
1.47 \mathrm{~km}^{2}\end{array}$ & $\begin{array}{l}0.9-0.93 \\
\left(1.47 \mathrm{~km}^{2}\right. \\
\text { fire })\end{array}$ & $\begin{array}{l}\text { "Near source", } \\
\text { less than } 0.5 \\
\text { hours (often } \\
\text { less than } 10 \\
\text { mins); } 5 \mathrm{hrs} \\
\left(\mathrm{A} ; 0.36 \mathrm{~km}^{2}\right. \\
\text { fire) and } 2 \mathrm{hrs} \\
\left(\mathrm{A} ; 1.47 \mathrm{~km}^{2}\right. \\
\text { fire) }\end{array}$ & & $\begin{array}{l}0.65\left(0.36 \mathrm{~km}^{2}\right. \\
\text { fire }), 1.0(1.47 \\
\left.\mathrm{km}^{2} \text { fire }\right) ; \\
1.2,1.4(\text { range } \\
\text { from data); } \\
3.6\left(1.47 \mathrm{~km}^{2}\right. \\
\text { fire }), 5.4(0.36 \\
\left.\mathrm{km}^{2} \text { fire }\right)\end{array}$ \\
\hline
\end{tabular}




\begin{tabular}{|c|c|c|c|c|c|c|}
\hline $\begin{array}{l}\text { Akagi et al., } \\
2012\end{array}$ & $\begin{array}{l}\text { Prescribed } \\
\text { chaparral } \\
\text { burn in U.S. } \\
\text { (California) }\end{array}$ & $\begin{array}{l}0.81 \mathrm{~km}^{2} ; \\
\text { Winds } \\
\text { between } 0.5- \\
2.2 \mathrm{~m}^{-1}\end{array}$ & 0.933 & \begin{tabular}{|l} 
"Nascent", \\
collected \\
600-1300 m \\
above the \\
plume; up to \\
12 hrs (P) \\
\end{tabular} & $\begin{array}{l}\text { In-plume } \\
\text { OH } \\
5.27 \times 10^{6} \\
\text { molec } \mathrm{cm}^{-3}\end{array}$ & $\begin{array}{l}0.8 \\
\mathrm{n} / \mathrm{a} \\
\mathrm{n} / \mathrm{a}\end{array}$ \\
\hline $\begin{array}{l}\text { ARCTAS } \\
\text { (Cubison et } \\
\text { al., 2011) }\end{array}$ & $\begin{array}{l}\text { Large boreal } \\
\text { wildfire in } \\
\text { N.W. } \\
\text { Saskatchewa } \\
\text { n }\end{array}$ & "Large" & $\begin{array}{l}\text { “Surface-to- } \\
\text { torching" } \\
\text { fire }\end{array}$ & $\left\{\begin{array}{l}\text { "Near-field"; } 5 \\
\text { hrs (P) }\end{array}\right.$ & $\begin{array}{l}\text { No } \\
\text { discussion }\end{array}$ & $\begin{array}{l}1.0 \\
1.44 \\
3.8\end{array}$ \\
\hline $\begin{array}{l}\text { SAMMBA } \\
\text { (Brito et al., } \\
2014 \text {; } \\
\text { Morgan et } \\
\text { al., 2019) }\end{array}$ & $\begin{array}{l}\text { Rainforest } \\
\text { fires in S.W. } \\
\text { Brazilian } \\
\text { Amazon }\end{array}$ & $\begin{array}{l}\text { No } \\
\text { discussion } \\
\text { (Brito); At } \\
\text { maximum } 5 \\
\mathrm{~km}^{2} \text { but } \\
\text { likely } \\
\text { smaller }\end{array}$ & $\begin{array}{l}\text { Not } \\
\text { explicitly } \\
\text { discussed } \\
\text { (Brito); } \\
\text { MCE of } \\
0.79 \\
\text { (Morgan) }\end{array}$ & $\begin{array}{l}\text { "“fresh", } \\
\text { "nearby"; } \\
>3 \text { hrs (A) } \\
\text { (Brito). } \\
\text { "Above the } \\
\text { fire" to } 3 \text { hrs } \\
\text { (A) (Morgan) }\end{array}$ & $\begin{array}{l}\text { No } \\
\text { discussion } \\
\text { (Brito and } \\
\text { Morgan) }\end{array}$ & $\begin{array}{l}1.0 \text { (Brito and } \\
\text { Morgan); } \\
2.4 \text { (Brito); } \\
\text { n/a }\end{array}$ \\
\hline $\begin{array}{l}\text { SEAC4RS } \\
\text { (Forrister et } \\
\text { al., 2015) }\end{array}$ & $\begin{array}{l}\text { Large } \\
\text { wildfire in } \\
\text { the U.S. }\end{array}$ & "Large" & $\begin{array}{l}\text { Smoldering, } \\
\text { with } \\
\Delta \mathrm{rBC} / \Delta \mathrm{CO} \\
\sim 2.5 \times 10^{-6}\end{array}$ & $\begin{array}{l}1 \mathrm{hr}(\mathrm{A}) \\
7 \mathrm{hrs}(\mathrm{A})\end{array}$ & $\begin{array}{l}\text { No } \\
\text { discussion }\end{array}$ & $\begin{array}{l}0.27 \\
1.9 \\
\mathrm{n} / \mathrm{a}\end{array}$ \\
\hline $\begin{array}{l}\text { BBOP } \\
\text { (Collier et } \\
\text { al., 2016) }\end{array}$ & $\begin{array}{l}\text { Wildfires in } \\
\text { the western } \\
\text { U.S. }\end{array}$ & $\begin{array}{l}\text { No } \\
\text { discussion }\end{array}$ & $\begin{array}{l}\text { Fresh: } \\
\text { range from } \\
0.86 \text { to } \\
0.96 \text {; aged: } \\
\text { range from } \\
0.8 \text { to } 0.99\end{array}$ & $\begin{array}{l}1-6 \mathrm{hrs}(\mathrm{A}) ; 6- \\
45 \mathrm{hrs}(\mathrm{A})\end{array}$ & $\begin{array}{l}\text { No } \\
\text { discussion }\end{array}$ & $\begin{array}{l}1.0 \\
1.9 \\
\mathrm{n} / \mathrm{a}\end{array}$ \\
\hline $\begin{array}{l}\text { DABEX } \\
\text { (Capes et } \\
\text { al., 2008; } \\
\text { Jolleys et } \\
\text { al., 2012) }\end{array}$ & $\begin{array}{l}\text { Agricultural } \\
\text { burns } \\
\text { (included } \\
\text { grasses, } \\
\text { shrubs) in } \\
\text { W. Africa }\end{array}$ & $0.01-0.1 \mathrm{~km}^{2}$ & $\begin{array}{l}\text { Smoldering } \\
\text { (visual } \\
\text { observation } \\
\text { s, Capes) }\end{array}$ & $\begin{array}{l}0 \text { hrs (flying } \\
\text { above the fresh } \\
\text { plumes) } \\
\text { (Capes), } \\
\text { "fresh" } \\
\text { (Jolleys); } \\
24-48 \text { hrs (P) } \\
\end{array}$ & $\begin{array}{l}\text { No } \\
\text { discussion }\end{array}$ & $\begin{array}{l}0.66 \text { (Jolleys), } \\
1.0 \text { (Capes); } \\
\text { n/a; } \\
0.55 \text { (Jolleys), } \\
2.2 \text { (Capes) }\end{array}$ \\
\hline $\begin{array}{l}\text { ACTIVE } \\
\text { (Jolleys et } \\
\text { al., 2012) } \\
\end{array}$ & $\begin{array}{l}\text { Eucalyptus } \\
\text { forests in N. } \\
\text { Australia }\end{array}$ & $\begin{array}{l}\text { No } \\
\text { discussion }\end{array}$ & $\begin{array}{l}\text { No } \\
\text { discussion }\end{array}$ & $\begin{array}{l}\text { "Fresh"; } \\
\text { up to } 24 \mathrm{hrs} \\
\text { (P) }\end{array}$ & $\begin{array}{l}\text { No } \\
\text { discussion }\end{array}$ & $\begin{array}{l}0.76 \\
\text { n/a; } \\
2.34\end{array}$ \\
\hline $\begin{array}{l}\text { BORTAS } \\
\text { (Jolleys et } \\
\text { al., 2015) }\end{array}$ & $\begin{array}{l}\text { Boreal forest } \\
\text { fires in N. } \\
\text { America } \\
\text { (Canada) }\end{array}$ & $\begin{array}{l}\text { No } \\
\text { discussion }\end{array}$ & $\begin{array}{l}\text { Fresh } \\
\text { plumes } \\
\text { were from } \\
\text { more } \\
\text { smoldering; }\end{array}$ & \begin{tabular}{|l} 
“Fresh"; \\
$24-120$ hrs (A)
\end{tabular} & $\begin{array}{l}\text { No } \\
\text { discussion }\end{array}$ & $\begin{array}{l}0.5 \\
\mathrm{n} / \mathrm{a} \\
8.6-9\end{array}$ \\
\hline
\end{tabular}




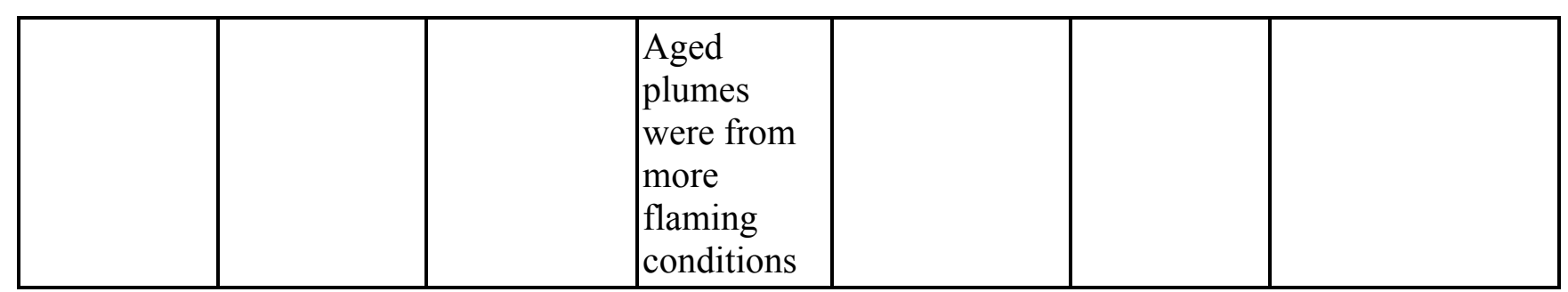




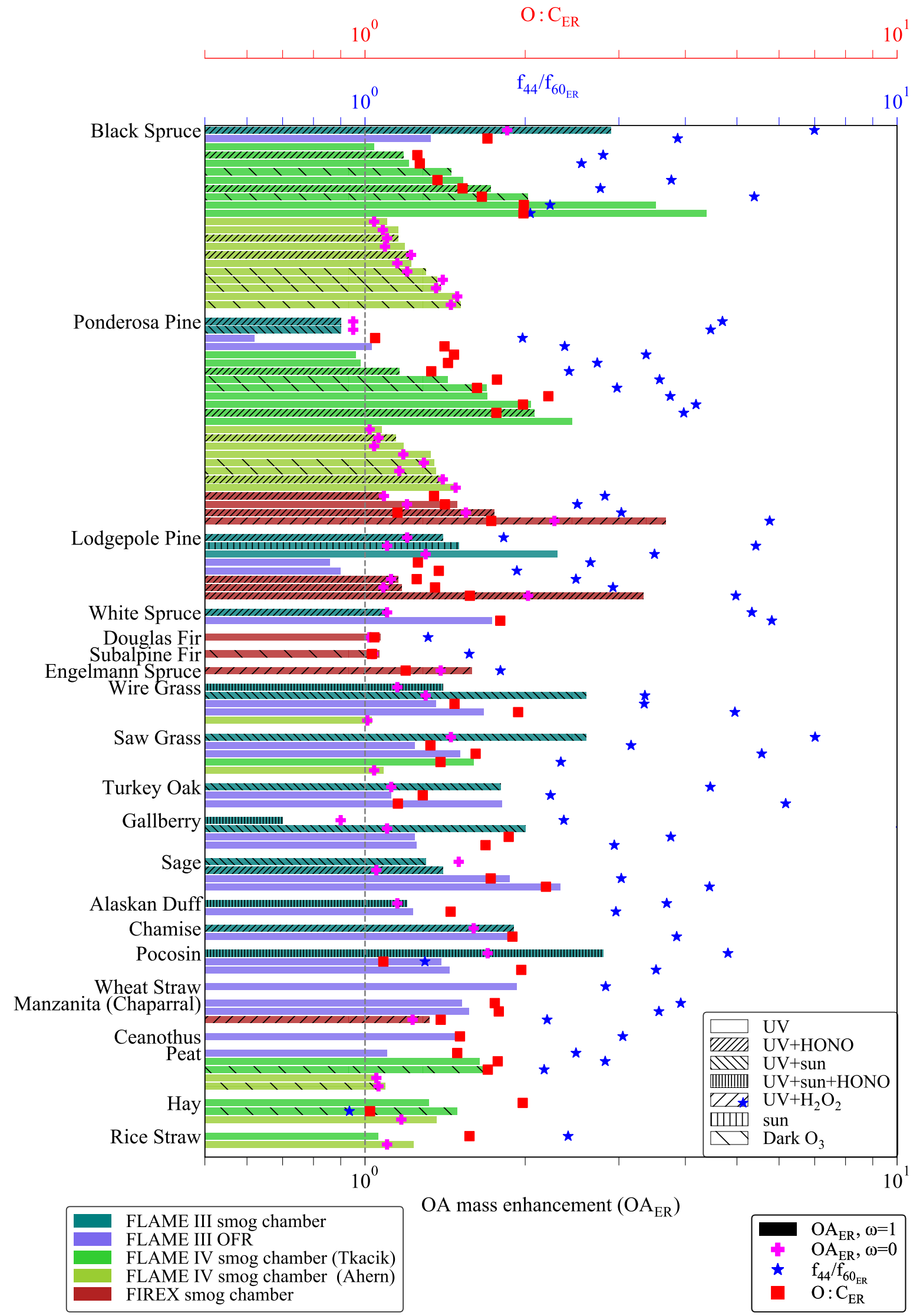


Figure S1. Results for each experiment within the laboratory campaigns of Figure 1C and D arranged by fuel type. Bars are OA mass enhancement $\left(\mathrm{OA}_{\mathrm{ER}}\right)$ for the $\omega=1$ case for the FLAME III, FLAME IV, and FIREX smog chambers (bottom $x$ axis). For the FLAME III OFR, the bars are the maximum $\mathrm{OA}_{\mathrm{ER}}$ (not corrected for wall losses). Magenta crosses are for the $\omega=0$ case for the FLAME III, FLAME IV, and FIREX smog chambers, when available. Blue stars are $f_{44} / f_{60_{E R}}$, and red squares are O:C $\mathrm{C}_{\mathrm{ER}}$ (top x axis). All metrics are lined up on the same $\mathrm{x}$ axis, although each $\mathrm{x}$ axis is provided separately for reference. The hatching for each $\mathrm{OA}_{\mathrm{ER}}$ bar represent the oxidant method used. The vertical grey dashed line at 1 indicates no change from the initial value of a given metric. 


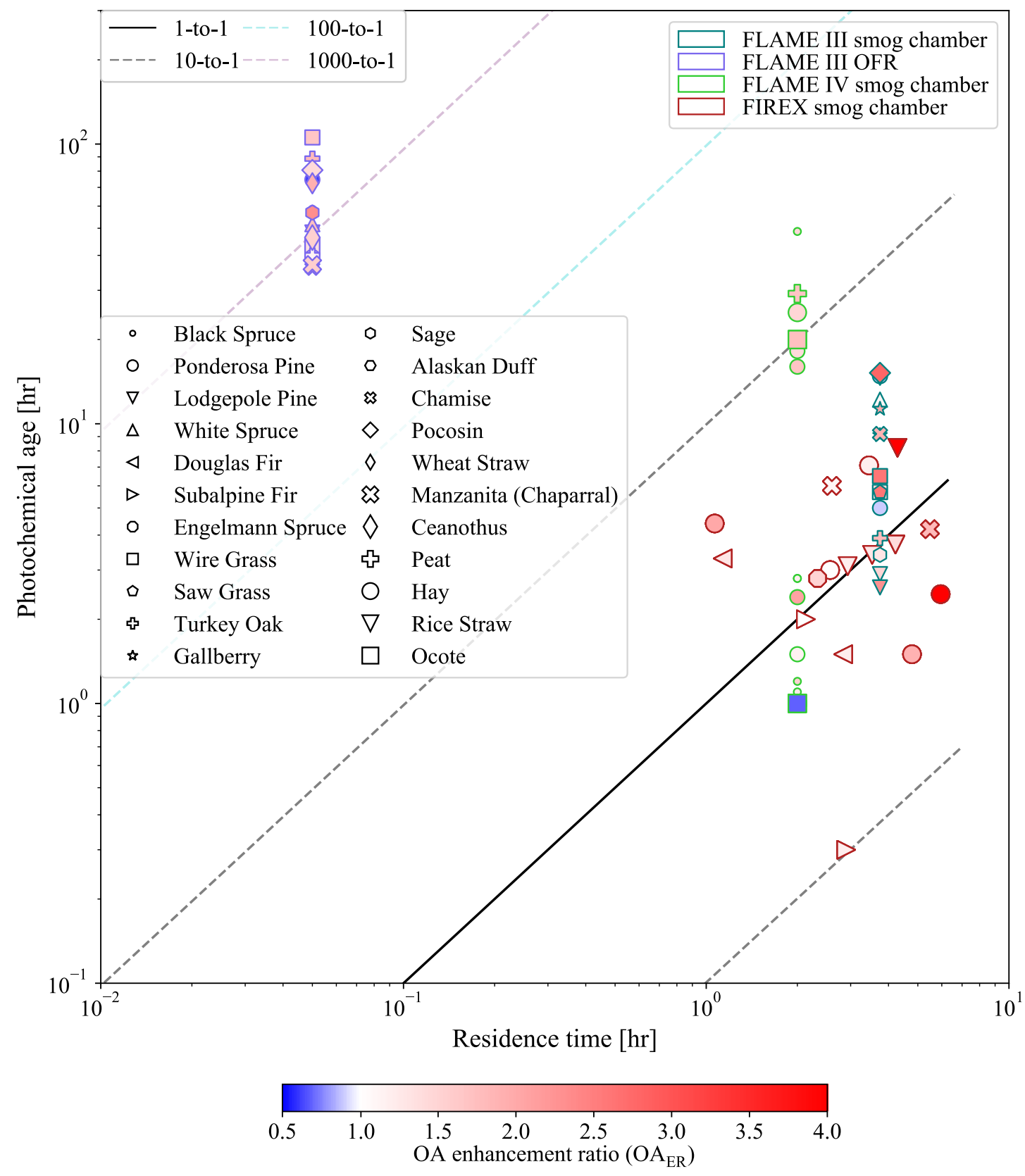

Figure S2. The estimated photochemical age for each residence (actual) time of each aging experiment within the laboratory campaigns of Figure 1B, colored by OA enhancement ratio $\left(\mathrm{OA}_{\mathrm{ER}}\right)$. Each symbol represents an individual fuel type. The outline color of each symbol indicates what study a given data point is from. Also shown are the 1-to-1, 10-to-1, 100-to-1, and 1000-to-1 lines. The FLAME III and FLAME IV campaigns did not provide individual residence times, and so the average residence times for each campaign are shown here. For the campaigns that provide both $\omega=1$ and $\omega=0$ data, we show the $\omega=1$ cases. 


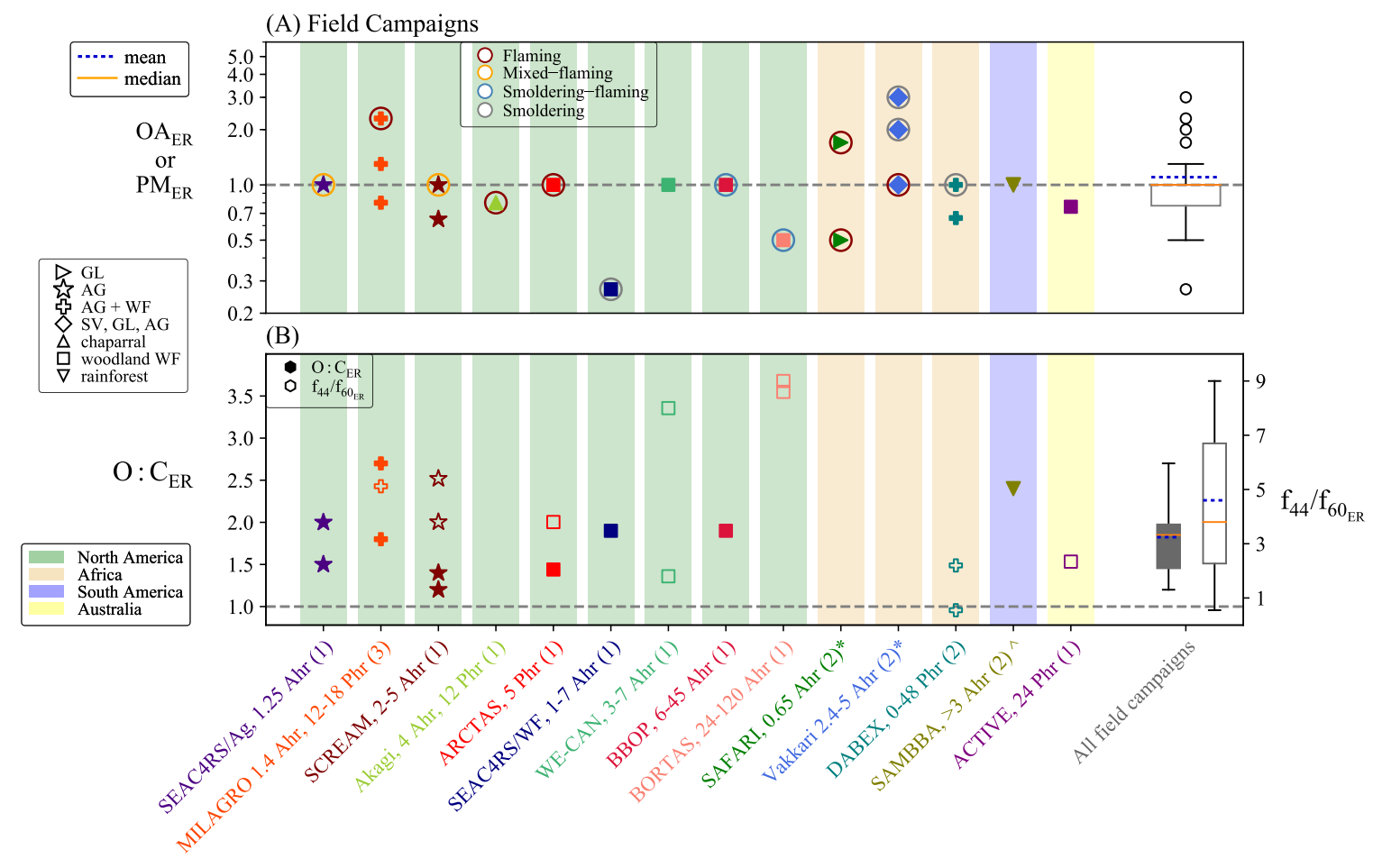

Figure S3. The field studies of Figure 1A, B arranged by geographic region. No published studies are available for Asia or Europe. 


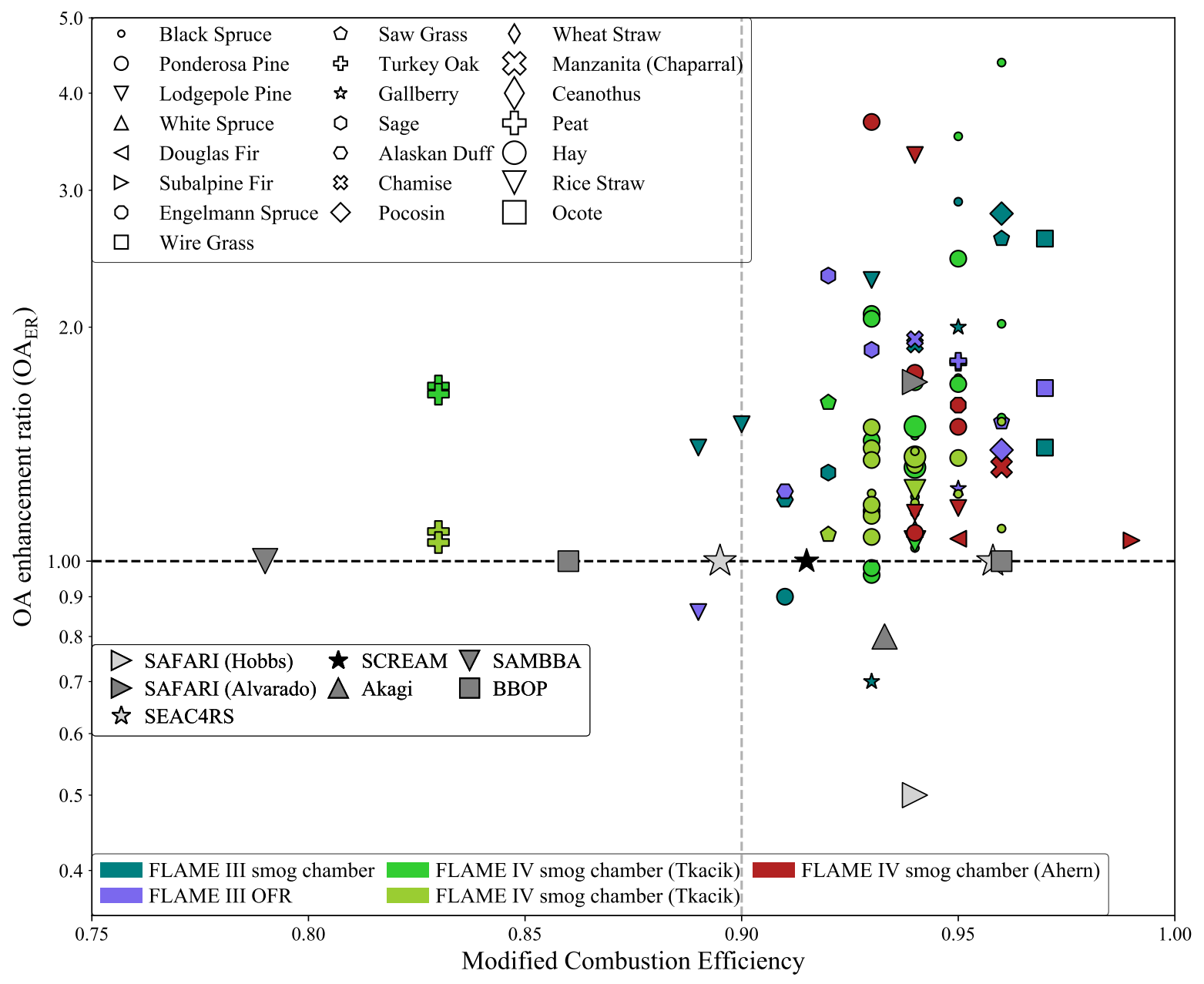

Figure S4. The OA enhancement ratio to the modified combustion efficiency (MCE) for each chamber for all experiments within the laboratory campaigns of Figure $1 \mathrm{~B}$ as well as field campaigns where MCEs were reported in the associated publications. Symbols indicate fuel type and colors indicate study type. The horizontal dashed black line at $\mathrm{OA}_{\mathrm{ER}}=1$ indicates no net change in OA mass from the initial mass. The vertical dashed grey line at $\mathrm{MCE}=0.9$ indicates the rough cutoff between flaming and smoldering conditions. MCE values $>0.9$ indicate more flaming conditions. MCE values $<0.9$ indicate more smoldering conditions. MCE values around 0.9 indicate mixed flaming and smoldering conditions. Also included on this figure are the studies that report MCE. The SEAC4RS and BBOP campaigns reported a range of MCE, indicated by multiple symbols showing the minimum and maximum MCE values. Similar to Figure 1A, we report both estimates of enhancement ratios for SAFARI (Hobbs et al., 2003; Alvarado and Prinn, 2009). For the laboratory campaigns that provide both $\omega=1$ and $\omega=0$ data, we show the $\omega=1$ cases. 

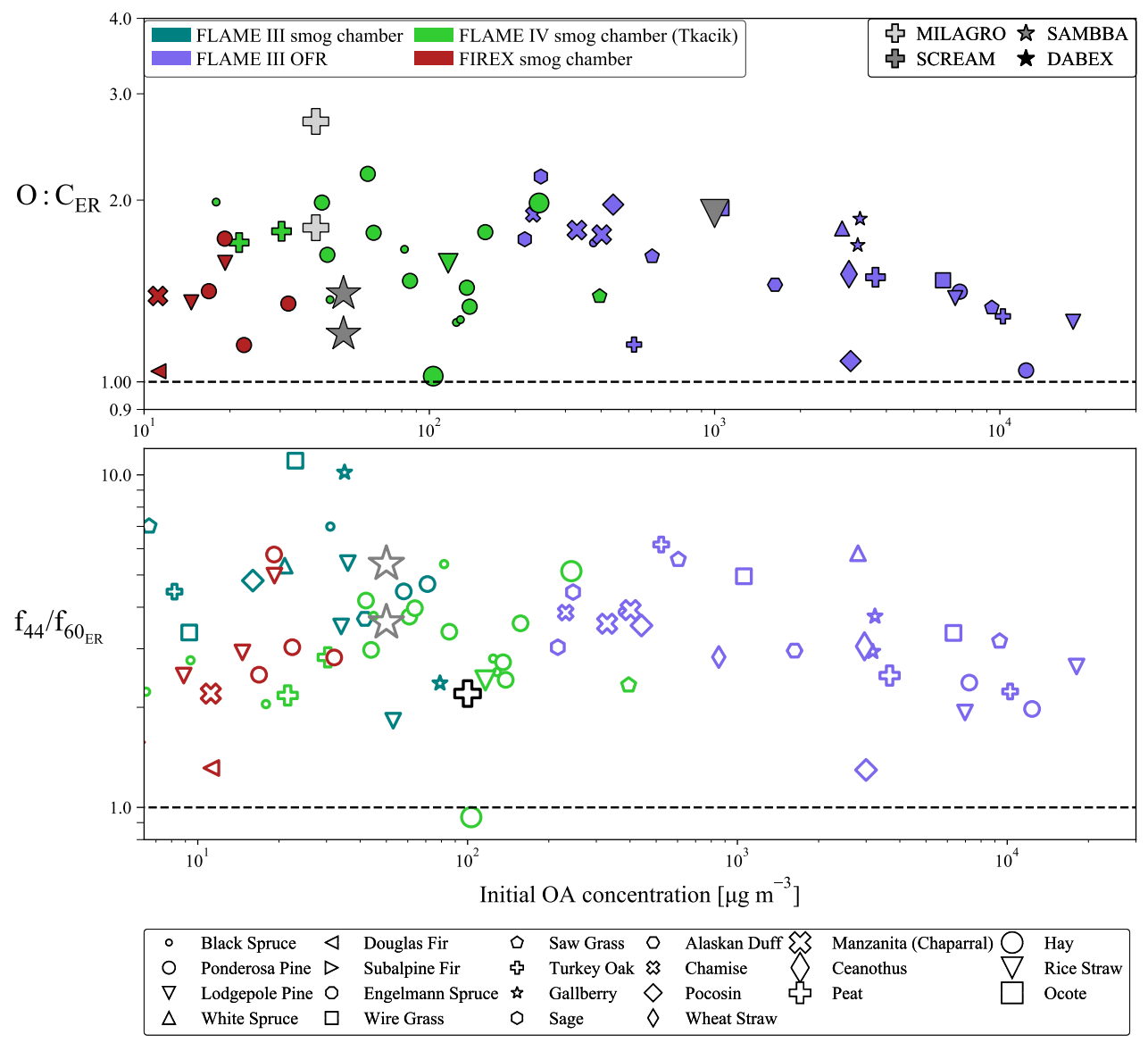

Figure S5. O: $\mathrm{C}_{\mathrm{ER}}$ (top panel; closed symbols) and $f_{44} / f_{60_{E R}}$ (bottom panel; open symbols) values to the initial $\mathrm{OA}$ concentration in $\mu \mathrm{g} \mathrm{m}^{-3}$ within each chamber for all experiments within the laboratory campaigns of Figure 1B. Symbols indicate fuel type and colors indicate study type. The dashed black line at 1 indicates no net change in either metric from their initial values. Also included are field campaign O: $\mathrm{C}_{\mathrm{ER}}$ and $f_{44} / f_{60_{E R}}$ values, where initial OA concentrations were available. For the laboratory campaigns that provide both $\omega=1$ and $\omega=0$ data, we show the $\omega=1$ cases. 

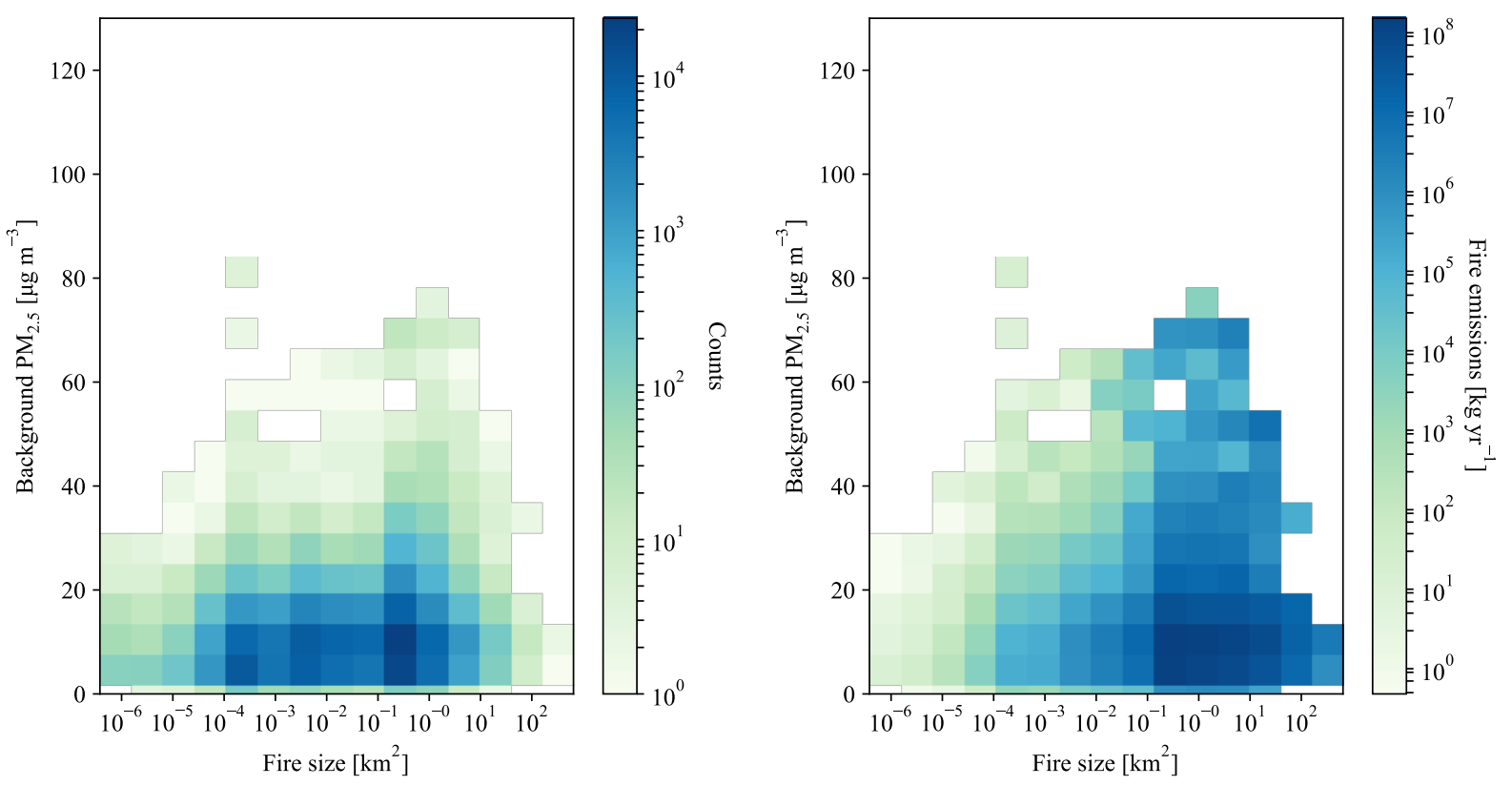

Figure S6. (Left) Two-dimensional histogram of the annual data for the United States in 2014 for the number of recorded fires by fire size in $\mathrm{km}^{2}$ blackened per day (that is, the total area in $\mathrm{km}^{2}$ burned per day) from the National Emissions Inventory (U.S. EPA NEI, 2014) against the nonsmoke background $\mathrm{PM}_{2.5}$ that each fire diluted into. The background $\mathrm{PM}_{2.5}$ is a seasonal median estimate of $\mathrm{PM}_{2.5}$ without wildland fire smoke influence. It was estimated by kriging daily 24-hr $\mathrm{PM}_{2.5}$ concentrations from the EPA Air Quality System (AQS) on days without a smoke plume overhead (according to the Hazard Mapping System fire and smoke product). The dataset is described in more detail in O'Dell et al. 2019. (Right) Total annual $\mathrm{PM}_{2.5}$ emissions in $\mathrm{kg}$ from each fire size for 2014 from the same dataset against the background $\mathrm{PM}_{2.5}$ that each fire diluted into. 


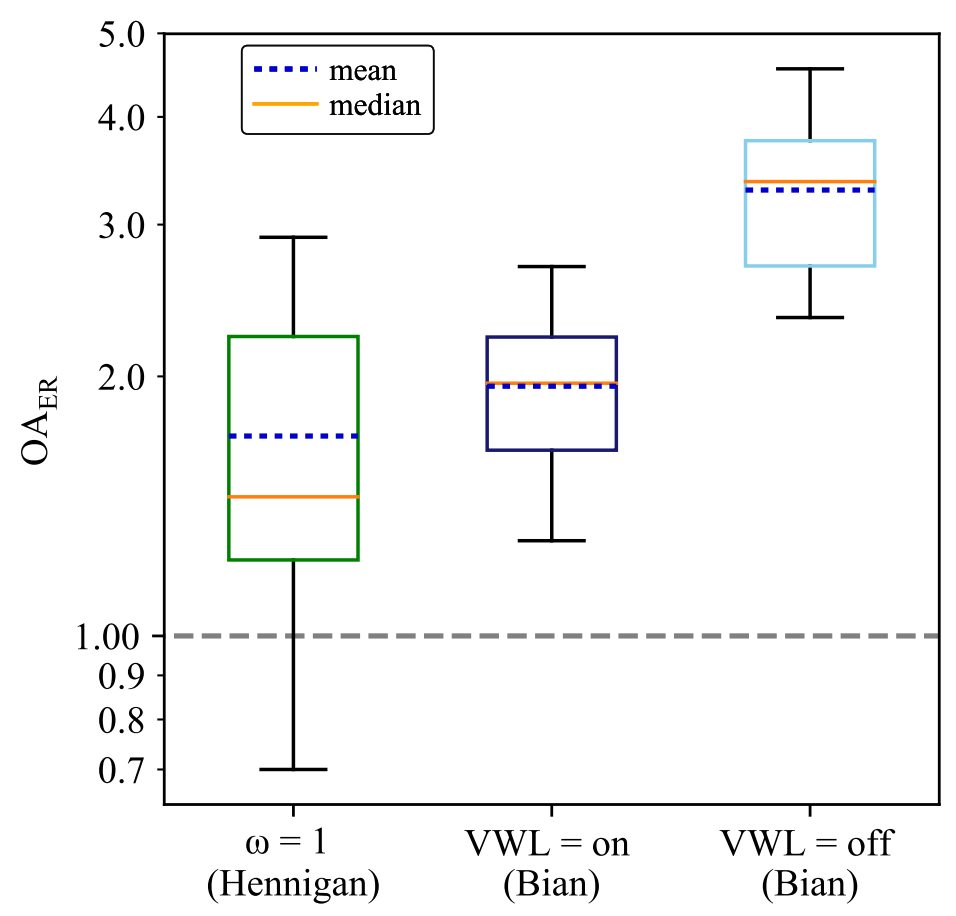

Figure S7. The box-and-whiskers for the OA enhancement ratios $\left(\mathrm{OA}_{\mathrm{ER}}\right)$ smog chamber at FLAME III (Hennigan et al., 2011) and the model results of Bian et al., (2017) for partitioning of vapors to the chamber walls on and off (vapor wall losses; VWL). With partitioning of vapors on, the simulated range of $\mathrm{OA}_{\mathrm{ER}}$ lies within the observed range. Without partitioning of vapors (i.e., if there were no losses of vapors to chamber walls), $\mathrm{OA}_{\mathrm{ER}}$ nearly doubles. Bian et al. (2017) used the assumption that $\omega=1$ for their analysis and so the Hennigan et al. (2011) results for this assumption are shown. The dashed grey line at $\mathrm{OA}_{\mathrm{ER}}=1$ indicates no change in $\mathrm{OA}_{\mathrm{ER}}$ with age. 
(A) Lower bound at $40^{\circ} \mathrm{C}$

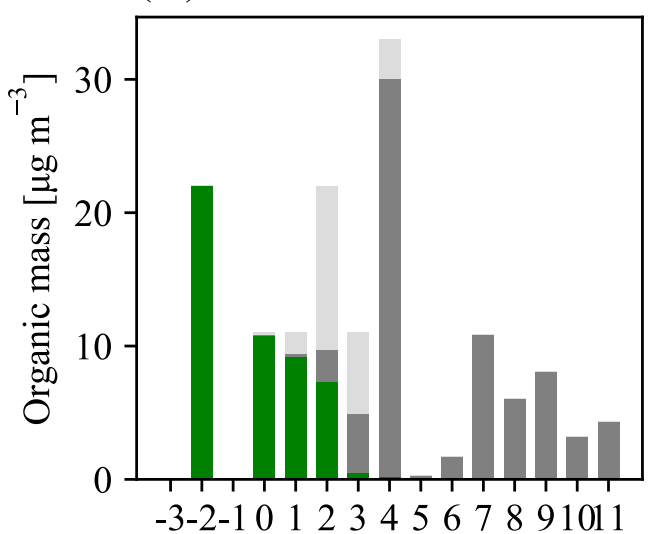

$\log _{10}\left(\mathrm{C}^{*}\right.$ at $\left.23^{\circ} \mathrm{C}\right)\left[\mu \mathrm{g} \mathrm{m}^{-3}\right]$

(C) Unheated $\left(23^{\circ} \mathrm{C}\right)$

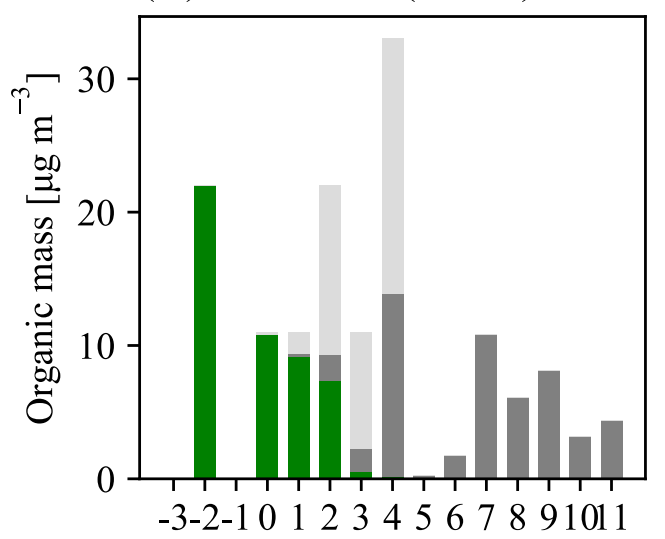

$$
\log _{10}\left(\mathrm{C}^{*} \text { at } 23^{\circ} \mathrm{C}\right)\left[\mu \mathrm{g} \mathrm{m}^{-3}\right]
$$

\section{Gas lost}

Evaporated aerosol lost

Gas transmitted

Evaporated aerosol transmitted

Aerosol transmitted

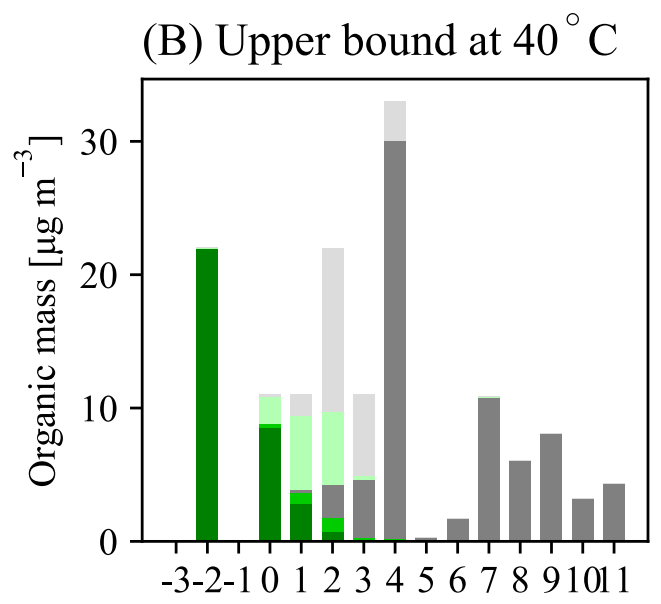

$$
\log _{10}\left(\mathrm{C}^{*} \text { at } 23^{\circ} \mathrm{C}\right)\left[\mu \mathrm{g} \mathrm{m}^{-3}\right]
$$

(D) OA enhancement ratios

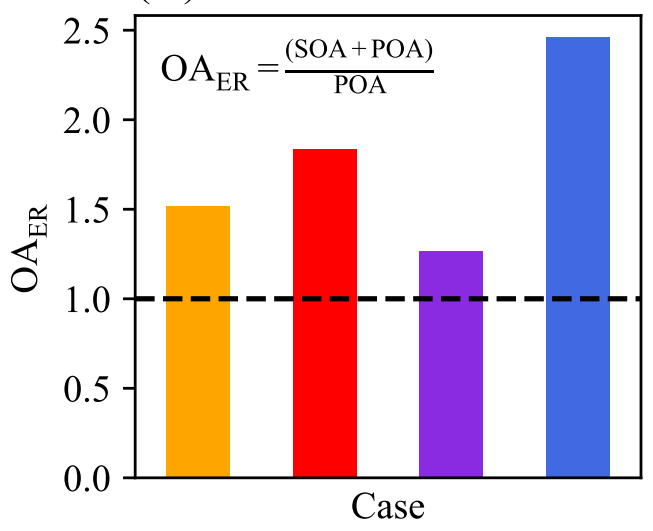

Figure S8. Estimated gas-phase losses of smoke to the transfer lines (tubing) between the burn chamber and the smog chamber, using the setup for FLAME III (Hennigan et al., 2011), assuming the line has been heated from $23^{\circ} \mathrm{C}$ to $40{ }^{\circ} \mathrm{C}$ and using the Teflon tubing model built in Pagonis et al. (2017). (A) The lower bound case assumes that upon heating from $23{ }^{\circ} \mathrm{C}$, the volatility distribution shifts but the aerosol does not have time to evaporate. (B) The upper bound case instead assumes that upon heating from $23{ }^{\circ} \mathrm{C}$, the volatility distribution shifts and the aerosol instantly evaporates to reach an instantaneous new equilibrium, which provides a reservoir of evaporated aerosol that may then be transmitted (and recondensed in the smog chamber) or lost to the transfer line. (C) The transmitted and lost volatility distribution if the tubing were not heated. (D) OA enhancement ratios $\left(\mathrm{OA}_{E R}\right)$ for each case compared to what 
$\mathrm{OA}_{\mathrm{ER}}$ is expected if no tubing was used. The dashed black line at $\mathrm{OA}_{\mathrm{ER}}=1$ indicates no change in $\mathrm{OA}_{\mathrm{ER}}$ with age. 